\title{
Phytoprotection
}

\section{Results of biological control of chestnut blight in Slovakia}

phytoprotection

\section{Gabriela Juhásová, Katarína Adamcíková et Cécile Robin}

Volume 86, numéro 1, avril 2005

URI : https://id.erudit.org/iderudit/011710ar

DOI : https://doi.org/10.7202/011710ar

Aller au sommaire du numéro

Éditeur(s)

Société de protection des plantes du Québec (SPPQ)

ISSN

0031-9511 (imprimé)

1710-1603 (numérique)

Découvrir la revue

Citer cet article

Juhásová, G., Adamcíková, K. \& Robin, C. (2005). Results of biological control of chestnut blight in Slovakia. Phytoprotection, 86(1), 19-23.

https://doi.org/10.7202/011710ar
Résumé de l'article

[Résultats de la lutte biologique appliquée sur Castanea sativa en Slovaquie] Le but de cette étude consistait à évaluer la vigueur de 2274 arbres de Castanea sativa dans la sous-région Stiavnicko-krupinská, en Slovaquie. Le degré de dommage des arbres a été évalué et exprimé selon une échelle de zéro à cinq et un indice de la vigueur des arbres, IhC, fut tiré de ces données Les valeurs de IhC variaient de 0,12 à 1,36. De 1992 à 1997, nous avons traité 714 chancres dans quatre sites avec des souches hypovirulentes de Cryphonectria parasitica obtenues de la Mycothèque INRA Clermont-Ferrand. Les traitements ont amené la cicatrisation d'environ 32,7 \% des chancres traités.
Tous droits réservés @ La société de protection des plantes du Québec, 2005
Ce document est protégé par la loi sur le droit d'auteur. L'utilisation des services d'Érudit (y compris la reproduction) est assujettie à sa politique d'utilisation que vous pouvez consulter en ligne.

https://apropos.erudit.org/fr/usagers/politique-dutilisation/ 


\title{
Results of biological control of chestnut blight in Slovakia
}

\author{
Gabriela Juhásová', Katarína Adamcíková1 and Cécile Robin²
}

Received 2005-04-06; accepted 2005-08-04

PHYTOPROTECTION $86: 19-23$

The health condition of Castanea sativa in the Stiavnicko-krupinská region of Slovakia was evaluated and the incidence of the fungus Cryphonectria parasitica was noted. A total of 2274 trees were examined. The degree of injury was expressed on a scale varying from zero to five and an index of health condition, IHC, was calculated from these data. The values of IHC varied from 0.12 to 1.36. From 1992 to 1997, we treated 714 cankers using hypovirulent strains of $C$. parasitica obtained from INRA Clermont-Ferrand. Callusing was observed on $32.7 \%$ of the treated cankers.

Keywords: Castanea satina, Cryphonectria parasitica, dsRNA, health condition, hypovirus, protection of woody plants.

\section{[Résultats de la lutte biologique appliquée sur Castanea sativa en Slovaquie]}

Le but de cette étude consistait à évaluer la vigueur de 2274 arbres de Castanea sativa dans la sousrégion Stiavnicko-krupinská, en Slovaquie. Le degré de dommage des arbres a été évalué et exprimé selon une échelle de zéro à cinq et un indice de la vigueur des arbres, IHC, fut tiré de ces données Les valeurs de IHC variaient de 0,12 à 1,36. De 1992 à 1997, nous avons traité 714 chancres dans quatre sites avec des souches hypovirulentes de Cryphonectria parasitica obtenues de la Mycothèque INRA Clermont-Ferrand. Les traitements ont amené la cicatrisation d'environ 32,7 \% des chancres traités.

Mots clés : ARN à double brin, Castanea satina, Cryphonectria parasitica, hypovirus, protection des plantes ligneuses, vigueur.

\section{INTRODUCTION}

Chestnut blight disease, caused by the fungus Cryphonectria parasitica (Murrill) Barr, can be controlled by means of a biological method based on the use of hypovirulent strains of the pathogen. This method is used in many regions of Europe to protect the chestnut Castanea sativa Mill. against the disease. Hypovirulence comprises all abnormal conditions that reduce the fitness of the pathogen, including infection by hypoviruses (Elliston 1982).

This biological control procedure is based on virulent and hypovirulent forms of the fungus $C$. parasitica that occur in nature. These strains have different physiological and morphological properties (Grente 1965). Hypovirulent isolates frequently have less pigment when grown in culture, fail to sporulate, and have significantly lower virulence to $C$. sativa than virulent isolates. The trees respond when infected by the hypovirulent strains by callus formation in the cankers. Abnormal cankers, from which the hypovirulent strains of the fungus are isolated, consist of exposed sapwood bordered by vigorous callus, with superficial infections radiating from the margins of the openings. Residues of fan-formed mycelia of $C$. parasitica occur only on the exposed wood and within fragments of dead bark adhering to the margins of the openings. The fans do not impair the cambial tissue because the host can respond vigorously to the hypovirulent fungus, preventing deeper penetration with the usual lethal consequences (Elliston 1985). Hypovirulent strains consistently contain hypoviruses whose genetic material is dsRNA (Anagnostakis and Day 1979). The final effect of the hypoviruses is to reduce mortality of infected trees.

The aim of this study was:

- to evaluate the health of $C$. sativa and the amount of infection by $C$. parasitica in the Stiavnickokrupinská region of Slovakia in Modry Kamen, Dolné Príbelce, Horné Príbelce, Stredné Plachtince and Horné Plachtince;

- to treat cankers with hypovirulent strains converted with French hypoviruses (INRA Clermont-Ferrand) and to evaluate the efficiency of biological control in the monitored localities.

\footnotetext{
1. Institute of Forest Ecology SAS Zvolen, Akademická 2, 94901 Nitra, Slovakia; corresponding author e-mail: nrueadam@savba.sk
} 2. INRA Bordeaux, B.P. 81, 33883 Villenave D'Ornon, France 


\section{MATERIALS AND METHODS}

The trees naturally infected by the fungus $C$. parasitica were treated using the method described by Grente (1981) and subsequently modified by Juhásová et al. (1997). Before applying the treatments, the health condition of all chestnuts was evaluated for the degree of injury using a six-degree scale (Juhásová and Bernadovicová 2001). Injury was defined as follows: category 0 , tree healthy without symptoms; category 1 , leaves are small and yellow; category 2, dry brown leaves and initial cankers with reddish discoloration; category 3, dry brown leaves and cankers with cracks on stem and main shoots; category 4 , more than $2 / 3$ of the crown with dead branches; category 5 , the tree is considered dead with many large cankers.

The degree of injury was expressed by the index of health condition IHC. The index is defined as follows:

$$
I H C=(1 n 1+2 n 2+3 n 3+4 n 4+5 n 5) / n
$$

where $\mathrm{n}=$ total number of evaluated trees, and $\mathrm{n} 1 \ldots \mathrm{n} 5=$ number of trees in the corresponding category of injury. IHC is only given for the localities with chestnut blight disease.

Treatments were performed on stems and branches of trees infected by virulent strains of the fungus that were ranked in categories of injury one to three. Only cankers that were accessible from the ground and by using an extension ladder were treated. Inoculation holes were made around the cankers, between the healthy and attacked parts of the host, 50 to $70 \mathrm{~mm}$ apart. These holes (5-8 $\mathrm{mm} \times 5-10 \mathrm{~mm}$, depending on the bark thickness) were made using an auger with flat edges so as to establish close contact between the hypovirulent mycelium of the fungus and the virulent mycelium causing the canker. Pellets containing the hypovirulent mycelium, prepared specifically for our trials by the Fytofarm (Phytofarm) of Bratislava and according to Grente (1965), were applied directly into the inoculation holes. Cubes of malt agar with hypovirulent mycelium were also used. The holes were then sealed with grafting wax. The degree of healing of the cankers treated in the years 1992 to 1997 was evaluated once the $\mathrm{yr}$ after treatment. Non-treated cankers in all localities (on the same stems and also on separated trees) were used as controls to compare the effect of biological control and to assess the natural spread of hypovirulence. The effect of treatment was evaluated visually (callus formation, enlargement of cankers outside the line of treatment). The size (width and length) of treated and non-treated cankers was measured in $\mathrm{mm}$.

As no hypovirulent isolates had previously been detected in Slovakia, virulent isolates of $C$. parasitica from Slovakia were converted into hypovirulent forms with French hypovirulent isolates maintained in the INRA Station d'Agronomie et Mycologie, Unité de Mycologie, in Clermont-Ferrand. Four new hypovirulent isolates were thus obtained. These new hypovirulent isolates (with dsRNA) were identified as TchA, TchD, TchC and TchE (Juhásová and BerthelaySauret 1993). Hypovirulent isolates TchA and TchD were both used for biological control of chestnut blight disease in Modry Kamen and Stredné Plachtince, and hypovirulent isolates TchC and TchE were used in Horné Plachtince.

\section{RESULTS}

The health of $C$. sativa trees and the extent of chestnut blight disease are summarized in Table 1. From a total of 2274 evaluated trees, 1459 (64.16\%) were found to be healthy.

All the localities in the Stiavnicko-krupinská region contained several stands with only healthy chestnut trees. A total of $815(35.8 \%)$ trees had chestnut blight disease, 403 of them in Modry Kamen (Table 1). There were also many infected trees in Stredné Plachtince (214 trees) and Horné Plachtince (192 trees). Few infected trees were found in Príbelce, where the advent of chestnut blight disease was more recent (since 2000). The IHC index varied from 0.12 (Horné Príbelce) to 1.36 (Horné Plachtince).

In 1992, only normally developing cankers (i.e. infected with virulent strains) were identified in the localities under study. The number of cankers varied from 1 to 15 per tree. Also, new cankers continued to form on the trees studied. The results of the biological control performed in the localities investigated are summarized in Table 2.

Table 1. Results of evaluation of the health of Castanea sativa and the presence of the fungus Cryphonectria parasitica

\begin{tabular}{|c|c|c|c|c|c|c|c|c|}
\hline \multirow[b]{2}{*}{ Locality } & \multirow{2}{*}{$\begin{array}{c}\text { Total number } \\
\text { of evaluated } \\
\text { trees }\end{array}$} & \multicolumn{6}{|c|}{$\begin{array}{l}\text { Number of infected trees } \\
\text { (for each degree of injury) }\end{array}$} & \multirow[b]{2}{*}{$\mathrm{IHC}^{\mathrm{a}}$} \\
\hline & & 0 & 1 & 2 & 3 & 4 & 5 & \\
\hline Horné Plachtince & 421 & 229 & 47 & 34 & 31 & 37 & 43 & 1.36 \\
\hline Stredné Plachtince & 581 & 367 & 63 & 24 & 34 & 31 & 62 & 1.12 \\
\hline Total & 2274 & 1459 & 301 & 108 & 118 & 124 & 164 & \\
\hline
\end{tabular}

a Index of health condition. 
From 1992 to 1997, a total of 714 cankers in all the localities were treated using hypovirulent strains of C. parasitica. The number of treated cankers in the experimental sites was as follows: 375 in Stredné Plachtince, 181 in Modry Kamen and 158 in Horné Plachtince. The treated cankers occurred on the stems and on branches. During the course of the study, $32.7 \%$ of all treated cankers were callusing (234 cankers), and callusing had started on the remaining treated trees. There were no differences in healing of cankers treated either with pellets or cubes of malt agar and no differences in healing of cankers treated with two different hypovirulent isolates (with TchA and TchD in Modry Kamen and Stredné Plachtince, and with TchC and TchE in Horné Plachtince). The proportion of treated cankers in all localities that were callusing usually increased each yr of the treatment.

The bark in the treated callusing cankers was swollen and the mycelium of the fungus was confined to the outer layers of the bark. In the treated younger cankers, the bark surface was cracked longitudinally and roughened. Some other treated cankers included exposed wood that was bounded by massive callus. On the exposed wood, residues of the mycelium were noted. The non-treated control cankers had enlarged considerably, indicating that growth of the fungal mycelium was very rapid in these cases. Within 3 to $4 \mathrm{yr}$ the fungus had encircled the branch or stem and parts distal to the cankers had dried up and died. Abundant red-orange stromata were present on the infected bark and were not formed on the bark of the treated cankers.

Up to yr 2002, no hypovirulent strains of $C$. parasitica were isolated in Slovakia. However, in that yr, we found cankers in Modry Kamen showing callusing in one of the experimental sites on trees that had not been treated. It thus appeared that the hypoviruses would have spread to the strains of $C$. parasitica causing the cankers.

Table 2. Results of biological control of chestnut blight disease in the Stiavnicko-krupinská region

\begin{tabular}{|c|c|c|c|c|c|}
\hline \multirow[b]{2}{*}{ Locality } & \multirow[b]{2}{*}{ Year } & \multicolumn{2}{|c|}{$\begin{array}{c}\text { Number of } \\
\text { evaluated trees }\end{array}$} & \multicolumn{2}{|c|}{ Number of cankers } \\
\hline & & Total & Infected & Treated & Callusing (\%) \\
\hline Modry & 1992 & 852 & 6 & 11 & 36.3 \\
\hline \multirow[t]{5}{*}{ Kamen } & 1993 & 822 & 10 & 14 & 35.7 \\
\hline & 1994 & 822 & 39 & 53 & 46.6 \\
\hline & 1995 & 822 & 8 & 36 & 38.3 \\
\hline & 1996 & 822 & 6 & 28 & 49.0 \\
\hline & 1997 & 822 & 28 & 39 & 50.0 \\
\hline Stredné & 1992 & 761 & 57 & 93 & 15.0 \\
\hline \multirow[t]{5}{*}{ Plachtince } & 1993 & 732 & 111 & 86 & 15.0 \\
\hline & 1994 & 634 & 90 & 95 & 22.1 \\
\hline & 1995 & 312 & 22 & 38 & 25.3 \\
\hline & 1996 & 312 & 18 & 24 & 30.0 \\
\hline & 1997 & 312 & 15 & 39 & 28.6 \\
\hline Horné & 1992 & 219 & 12 & 28 & 15.1 \\
\hline \multirow[t]{5}{*}{ Plachtince } & 1993 & 185 & 16 & 30 & 39.2 \\
\hline & 1994 & 172 & 28 & 51 & 40.0 \\
\hline & 1995 & 172 & 8 & 16 & 31.0 \\
\hline & 1996 & 172 & 12 & 21 & 29.6 \\
\hline & 1997 & 172 & 6 & 12 & 41.3 \\
\hline \multirow[t]{6}{*}{ Total } & 1992 & 1832 & 75 & 132 & 22.1 \\
\hline & 1993 & 1739 & 137 & 130 & 20.9 \\
\hline & 1994 & 1628 & 157 & 199 & 36.2 \\
\hline & 1995 & 1306 & 38 & 90 & 31.5 \\
\hline & 1996 & 1306 & 36 & 73 & 36.2 \\
\hline & 1997 & 1306 & 49 & 90 & 39.9 \\
\hline
\end{tabular}




\section{DISCUSSION}

The first application of a biological programme for the control of chestnut blight using hypovirulent strains of the pathogen in Europe was conducted in southern France in the years 1967 to 1972, and it yielded surprisingly positive results. Those were the first significant successes in attempting to control this important disease (Grente and Berthelay-Sauret 1969, 1978). The present study was conducted as a followup to previous studies and to other studies conducted in France to reinforce our confidence in the efficiency of this control measure. Treated cankers on infected trees were callusing and hypovirulent strains of the pathogen spread to non-treated chestnuts. More than $70 \%$ of treated chestnuts survived compared with a $90 \%$ mortality of the non-treated trees; $5 \mathrm{yr}$ later, hypovirulent strains were found on non-treated chestnuts 5 to $10 \mathrm{~m}$ from the treated trees. Insects were thought to have been the probable carriers spreading the hypovirulent strains to newly attacked chestnuts (Grente and Berthelay-Sauret 1969, 1978). One explanation for the lack of efficiency in the present study might come from a difference in the ecosystems. In France and Italy, where hypovirulence was first found, chestnut regeneration has continued with little or no competition from other plant species (MacDonald and Fulbright 1991). Another possibility is that hypoviruses may not be readily transmitted in this C. parasitica population. In Hungary, a similar biological programme was initiated in two localities (Ágfalva and Zengovárkony) in 1997 where Hungarian hypovirulent strains were used. The rate of callusing of the treated cankers in these two localities varied from 80 to $90 \%$ (Radócz 2002). Compared with the present results of our first attempt to use hypovirulent strains in Slovakia, the study in Hungary was more successful. Indeed, in our first tests, the number of callusing cankers was not more than $50 \%$. Grente and Berthelay-Sauret (1969) found hypovirulent strains on non-treated cankers within $5 \mathrm{yr}$ after treatment. We found the first callusing cankers on non-treated trees in 2002, $10 \mathrm{yr}$ after treatments were initiated in the area.

Our previous trials of treatment of chestnut blight cankers with hypovirulent strains were conducted in the Malé Karpaty region (Slovakia) (Juhásová et al. 1997), where the same hypovirulent strains (TchA, TchE, TchD, TchC) and methods of treatment used in the present study were then also employed. One yr after applying the curative treatments (Juhásová et al. 1997), the following results were obtained: $41.04 \%$ of treated cankers had been confined, $22.52 \%$ had started to callus over, and cankers had enlarged on $40.54 \%$ of the trees (and some had died). In the present study (Modry Kamen, Stredné Plachtince and Horné Plachtince), for the same period, treated cankers on stems and lower branches on 5- to 350 -yr-old trees had callused in a proportion of 15 to $39.2 \%$. Present results are similar to those obtained in the Malé Karpaty region and confirmed the effectiveness of Slovak-converted hypovirulent strains of C. parasitica. Some treatments might have failed previously because of inadequate contact of virulent hyphae with hypovirulent hyphae in the cankered tissue due to the desiccation of the pellets. These conditions were somewhat remedied in the present tests by covering the wounds with grafting wax. One other possible explanation might have been genetic incompatibility between the virulent and hypovirulent mycelium. It is known that transmission of hypoviruses is $100 \%$ successful only when both types of mycelium have the same vegetative compatibility (vc) genotypes. Indeed, heteroallelism at one or more vegetative incompatible (vic) loci generally reduces the possibility of transmission of the virus (Cortesi et al. 2001).

The strains used for canker treatment were hypovirulent but grew and sporulated so poorly that their persistence was limited. In addition to treated cankers in the present tests, indications were obtained that hypoviruses had spread to non-treated cankers in Modry Kamen. However, a combination of several favourable factors may be involved in the natural spread of hypovirulence. The sporulation of hypovirulent strains is markedly lower than the sporulation of virulent strains of C. parasitica. As hypoviruses would be present in conidia and not in ascospores (Bissegger et al. 1997), transmission of hypovirulence mostly occurs by means of conidia. However, about 10 to $50 \%$ of the conidia produced by hypovirulent strains do not contain the hypovirus and these can give rise to fully virulent mycelium (Anagnostakis 1995).

The evaluation of the condition of $C$. sativa in the present study indicates that $64 \%$ of trees were healthy. Of the treated cankers in three experimental localities from 1992 to 1997, 32.7\% were callusing, a figure which may appear to be low. However, this proportion usually increased each yr of treatment (Table 2). Overall, the biological control programme in the Stiavnicko-krupinská region was therefore effective. Discovery of the natural spread of the virus responsible for hypovirulence is also a promising outcome for chestnut protection against chestnut blight disease in Slovakia. The assumption is that for hypovirulence to be successful, a constant reservoir or source of hypovirulent inoculum must be present to spread and interact with the natural population of $C$. parasitica (MacDonald and Fulbright 1991).

\section{ACKNOWLEDGEMENTS}

The authors thank Monika Halandová and Dusan Halanda for technical assistance. This work was supported by the Grant Agency for Science, VEGA, Grant No. 2/4020/04, and by project APVT 51015602. 


\section{REFERENCES}

Anagnostakis, S.L. 1995. The pathogens and pests of chestnuts. Adv. Bot. Res. 21 : 125-145.

Anagnostakis, S.L., and P.R. Day. 1979. Hypovirulence conversion in Endothia parasitica. Phytopathology 69 : 12261229.

Bissegger, M., D. Rigling, and U. Heiniger. 1997. Population structure and disease development of Cryphonectria parasitica in European chestnut forests in the presence of natural hypovirulence. Phytopathology 87 : 50-59.

Cortesi, P., C.E. McCulloch, H. Song, H. Lin, and M.G. Milgroom. 2001. Genetic control of horizontal virus transmission in the chestnut blight fungus, Cryphonectria parasitica. Genetics 159 : 107-118.

Elliston, J.E. 1982. Hypovirulence. Pages 1-33 in I.D.S. Ingram and P.H. Williams (eds.), Advances in plant pathology. Academic London Press, London.

Elliston, J.E. 1985. Characteristics of dsRNA-free and dsRNA-containing strains of Endothia parasitica in relation to hypovirulence. Phytopathology $75: 151-158$.

Grente, J. 1965. Les formes hypovirulentes d'Endothia parasitica et les espoirs de lutte contre le chancre du châtaignier. C. R. Acad. Agric. France 51 : 1033-1037.

Grente, J. 1981. Les variants hypovirulents de I'Endothia parasitica et la lutte biologique contre le chancre du châtaignier. INRA, Clermont Ferrand, France. 194 pp.
Grente, J., and S. Berthelay-Sauret. 1969. L'hypovirulence exclusive, phénomène original en pathologie végétale. C. R. Acad. Sci. Paris $268: 2347-2350$.

Grente, J., and S. Berthelay-Sauret. 1978. Biological control of chestnut blight in France. Pages 30-34 in W.L. McDonald., F.C. Cech, J. Luchok and C. Smith (eds.), Proceedings of the American chestnut symposium. West Virginia University Press, Morgantown, WV.

Juhásová, G., and S. Bernadovicová. 2001. Cryphonectria parasitica (Murr.) Barr and Phytophthora spp. in chestnut (Castanea sativa Mill.) in Slovakia. For. Snow Landsc. Res. $76:$ 373-377.

Juhásová, G., and S. Berthelay-Sauret 1993. Health conditions of Castanea sativa Mill., incidence of the fungus Cryphonectria parasitica (Murr.) Barr and possibilities of its biological control in Slovakia. Biotechnologia $1: 55$ 58.

Juhásová, G., J. Satko, M. Bauer, and S. Berthelay-Sauret. 1997. Application of the fungus Cryphonectria parasitica (Murr.) Barr hypovirulent strains for the protection of Castanea sativa in Small Carpathians region. Biológia $52: 499-501$

MacDonald, W.L., and D.W. Fulbright. 1991. Biological control of chestnut blight: use and limitations of transmissible hypovirulence. Plant Dis. 75 : 656-661.

Radócz, L. 2002. A héjasok növényvédelme [Protection of scalys]. Szaktudás Kiadó Ház, Budapest. 256 pp. 